DOI: https://doi.org/10.31933/dijemss.v2i2

Received: 16 September 2020, Revised: 26 October 2020, Publish:19 December 2020

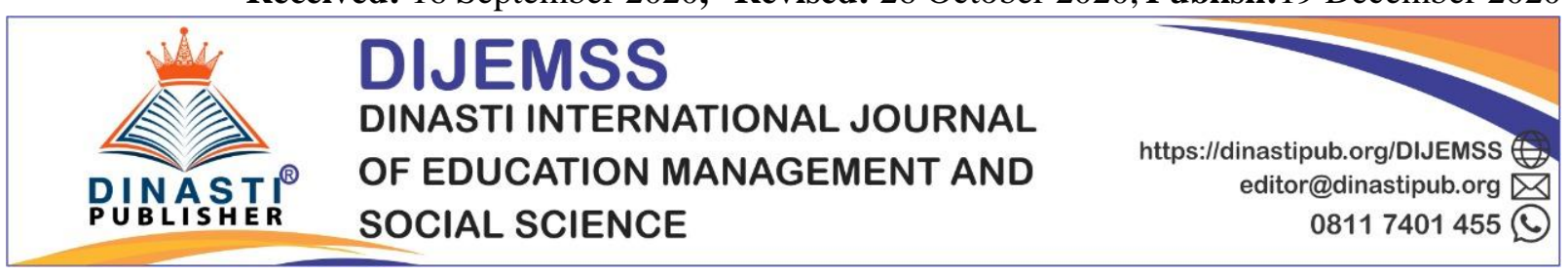

\title{
THE IMPACT ON TURNOVER INTENTION THAT VIEWED THROUGH CAREER DEVELOPMENT AND WORK ENVIRONMENT WHICH MEDIATED BY WORK SATISFACTION AT PT. SINAR
} ANTJOL 1942

\author{
Elsa Aprianis Marpaung ${ }^{1}$, Singmin Johanes Lo ${ }^{2}$ \\ 1) Mercu Buana University, Jakarta, Indonesia, elsaamarpaung@gmail.com \\ ${ }^{2)}$ Mercu Buana University, Jakarta, Indonesia, singmin.johanes@ mercubuana.ac.id
}

Corresponding Author: Elsa Aprianis Marpaung

\begin{abstract}
This research aims to evaluated and analyzed those influence of career development and work environment towards turnover intention which mediated by employee work satisfaction at PT. Sinar Antjol 1942. This research was conducted from October 2019 to April 2020 at PT Sinar Antjol Jakarta. Research data was questionnaire that calculated by Slovin formula with sample of 120 respondents out of 170 employees who had standard error of 5\%. Data were analyzed by SEM (Structural Equation Modeling) method with path analysis application SmartPLS (Partial Least Square) version 3.2.9 Windows. The results showed that career development and work environment had negative impact over turnover intention. Meanwhile, work satisfaction has succeeded in mediated between career development and work environment towards turnover intention.
\end{abstract}

Keywords: Career development, work environment, work satisfaction, turnover intention.

\section{INTRODUCTION}

Inclination (intention) is an desires that arises from individual to do something. Meanwhile, turnover is the stopping of an employee from working voluntarily or moving from work to another workplace. High turnover was indicated that employees do not like working in organization.

PT Sinar Antjol is an organization which engaged in manufacturing and established on August 29, 1942. The quality products which earned by PT Sinar Antjol inseparable from quality of its human resources. A phenomenon which often occurs at PT Sinar Antjol was while company's performance is good, there had an employee behavior which could damage the company's performance, either directly or indirectly. One form of employee behavior is turnover intention.

The author was conducted an interview with HRD Manager of PT Sinar Antjol regarding problems in Human Resources division where the results of interview explained that the 
employees felt they did not find comfort this causing employee's desire to resign was increased. These discomfort could be seen from coworkers' complaints against HRD division directly when speaking in free time such as wages that are deemed unsuitable, unclear career paths, inappropriate workloads and inadequate facilities. The resource person told that this happened due to employee dissatisfaction with the company as previously described regarding salaries, career paths, workloads and work facilities. From these four reasons, the strong influence on satisfaction which ultimately leads to the desire to resign according to resource person was career development and work environment. In terms of career development itself, the resource person explained that the lack of work-related training which should be able to help employees to complete their work besides the employees do not have opportunity to get promotion. This possible because the condition of company is a family company. In terms of work environment, the resource person said that the condition of work tools in the company still incomplete, the company has not responded positively to the application to fulfill the completeness of work, so the completeness of work used by employees is getting worn out, not keeping up with the times. Also, the relationship between colleagues that sources often finds conflict between superiors and subordinates which leads work environment less conducive or discomfortable with one another. The resource person were explained that another problem faced was finding new candidates. New candidates for PT Sinar Antjol were selected by ODR (One Day Recruitment) system meaning that all stages of psychological tests and interviews for new candidates were passed in one day and decided on that day. This ODR was conducted 2 times a month, which means that every month there are requests of new candidates. In addition, the turnover rate owned by company shows a fluctuating condition where the conditions was unstable and shows symptoms that not constant and always changing, while the company tried to reduce these turnover rate by targeting a maximum turnover rate of $8 \%-10 \%$ per year.

Previous research were found that the link between these problems. Yanjun Guan's research (2017) were explained that Career Development was positively related to Work Satisfaction, Eun Kyoung Chung's research (2017) explained that there had positive influence from work environment to Work Satisfaction which arises by an employee work motivation, Yasar Research and Nugraheni (2017) said that career development had significant impact on Turnover Intention, however, in Saklit's research (2017) which stated that career development had no impact on turnover intention, so there has gap which could triggered on emergence of mediating variables. Research by Irvianti and Verina (2015) shows that there had partial and simultaneous influence between Work Environment to Turnover Intention , but in Tobias Murtantyo's research (2015) which explained that work environment had positive impact towards Turnover Intention, so there had research gap which could triggered on the emergence of mediating variable. Research by $\mathrm{Na} \mathrm{Li}$, Lichuan Zhang (2019) which explained that work satisfaction had negative and significant influence over Turnover Intention. Beside that, in Yanjun Guan (2017) work satisfaction had succeeded in being an intervening variable between career development and turnover intention, whilst in Eun Kyoung's research (2017) work satisfaction has seen was mediated work environment to turnover intention.

From these explanation above, there were suggestions that career development and work environment which not done yet optimally so work satisfaction to organization was low, in resulting less turnover intention. Based on this background of problems, researchers were interested to carried out the research which related to "The Impact on Turnover Intention that viewed through Career Development and Work Environment and mediated by Work Satisfaction at PT. Sinar Antjol 1942". 


\section{LITERATURE REVIEW Career Development}

According to Kasmir (2016:140) which defined that employee development is a process to refresh, develop skills, talents, interests and employee behavior. According to Mathias and Jackon (2010:303) which stated that development is an effort to improve the ability of employees to handle various tasks and foster its employee abilities beyond those required by current jobs. In this research, The Dessler's theory which stated that career development is a series of longlife activities that contribute to exploration, formation, success and fulfillment of someone career. Career development according to Dessler in cashmere that could be done through education, transfer between sections (mutations/rotations) and promotion (Kasmir, 2016).

\section{Work Environment}

According to Sedarmayanti (2015) work environment is the whole tools and materials surround by environment where a person works, work method and work arrangement both individual and as a group. According to Sutrisno (2011:118) Work environment is the whole work facilities and infrastructure surrounds employees when doing work which had impact to the implementation of work. Sedarmayanti (2015) explained that work environment was divided into two, such as physical environment and non-physical environment.

\section{Work Satisfaction}

According to Robbin and Judge (2013:108) Work Satisfaction is a picture of positive feelings from individuals about their work, employees who were satisfied with their work and have high positive feelings about the work that they are doing. Noe et al (2015:468) was define work satisfaction is a feeling of pleasure as result from perception towards person's job fulfills or allows the fulfillment of important work values from that person. According to Luthan (2008:431) work satisfaction is a characteristic and challenges that arise in work that determine satisfaction. The dimensions of work satisfaction according to Luthan were that job itself, salary/wages, promotions, bosses and co-workers (Luthan, 2008:431).

\section{Turnover Intention}

According to Robbins and Coulter (2012:373) turnover intention is the withdraw from a company either voluntarily or involuntarily. According to Dessler (2015:372) the costs which arise from Turnover Intention in companies were divided into The tangible costs such as recruitment fees, screening, interviews, applicant tests, as well as salary fees when new employees are oriented and trained and also the costs that cannot be seen was lost productivity for the new employee (who are less productive initially), the cost of leadership for new employee. According to Armstrong (2009:201) reasons to leaving work probably occur due to higher pay, better career paths, better opportunities to develop skills, better security, better working conditions, unable to cope with work, bad relations with superiors, poor relations with peers, harassment, personal reasons such as pregnancy, illness, move away from occupied areas.

\section{Conceptual Framework}

The research conceptual framework model was described as follows: 


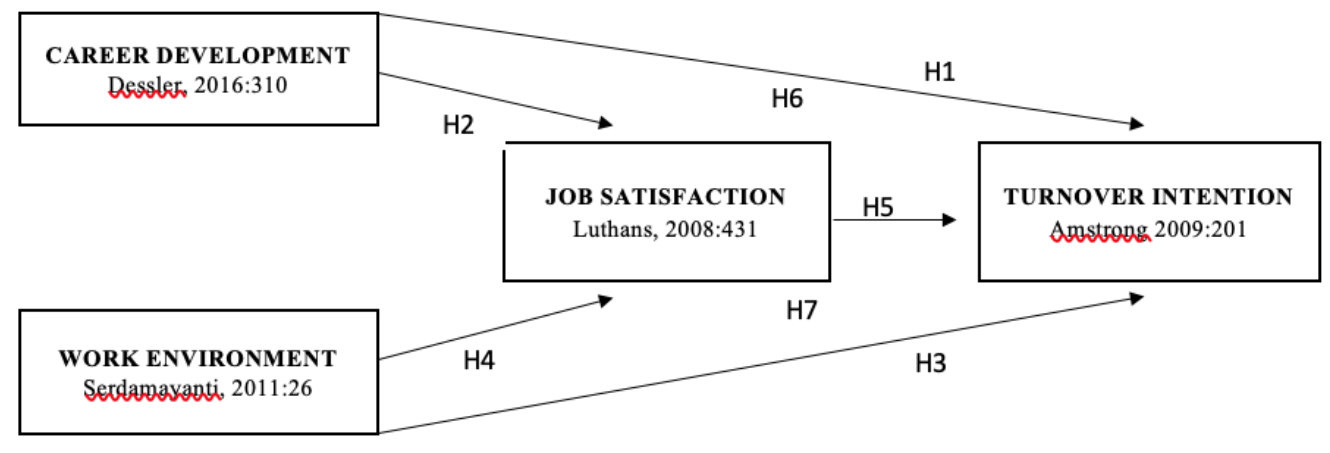

Figure 1. Conceptual Framework

\section{Hypothesis}

H1: Career development had negative impact on turnover intention.

$\mathrm{H} 2$ : Career development had positive and significant impact on work satisfaction.

H3: The work environment had negative impact on turnover intention.

H4: The work environment had positive and significant influence on work satisfaction.

H5: Work satisfaction had negative and significant influence on turnover intention.

H6: Career development had negative and significant impact on turnover intention which mediated by work satisfaction.

H7: Work environment had negative and significant impact towards turnover intention which mediated by work satisfaction.

\section{RESEARCH METHODS}

The method used was descriptive method with quantitative approach and causal research method. Research object was the employees of PT Sinar Antjol 1942 with total of 120 respondents filled out the questionnaire, samples were taken by Slovin formula from total population of 170 employees. The sampling technique used quota sampling then data were analyzed by SmartPLS (Partial Least Square) with assist of path analysis application.

\section{RESULT AND DISCUSSION Frequency Distribution}

Based on these questionnaires results that have been distributed, it was found that men were $62.5 \%$, while women were $37.5 \%$. In terms of age, most of them were over 40 years old at $27.5 \%, 33.33 \%$ for those over 30 to 40 years old and the remaining was $39.16 \%$ who aged 20 to 30 years. Meanwhile, for the length of work, there were $60.83 \%$ of employees who worked 1 to 5 years, $21.66 \%$ of employees who had worked for more than 5 to 10 years, while as many as $13.33 \%$ employees who worked for more than 10 to 15 years and employees who worked for more than 15 years of $4.16 \%$. Based on department/divisions. it was obtained from Maintenance Department as many as $8.33 \%$, Production dept as many as $7.50 \%$, Engineering and Improvment dept as many as $8.33 \%$, PPIC dept as many as $9.16 \%$, R\&D Dept around of 9.16\%, Dept. PGS and sales as many as 9.16\%, logistics dept around of 10.83\%, HRD and 
PGA as many as $9.16 \%$, Procurement of $7.5 \%$, MIS around $9.16 \%$, Accounting as many as $9 \%$, Finance as many as $6 \%$ and secretion as many as $0.83 \%$.

\section{Outer Model Evaluation}

According to Ghozali \& Latan (2015) stated that an indicator which considered to have a high level of validity which is if it has a loading factor value greater than 0.70 . However, these loading factor of 0.50 to 0.60 still acceptable. Loading factor value used in this research was $>$ 0.6 so if loading factor value was $<0.6$ from estimation result of measurement model (outer model),then it will be excluded from the model and recalculated again (outer model).

Table 1. Convergent Validity 1

\begin{tabular}{|c|c|c|}
\hline Variable & Indicator & Outloading \\
\hline \multirow{5}{*}{$\begin{array}{l}\text { Carrier Develo pment } \\
\text { (X1) }\end{array}$} & PK1 & 0.769 \\
\hline & PK2 & 0.864 \\
\hline & PK3 & 0.854 \\
\hline & PK4 & 0.934 \\
\hline & PK5 & 0.785 \\
\hline \multirow{6}{*}{$\begin{array}{l}\text { Work Enviranment } \\
\text { (X2) }\end{array}$} & LK1 & 0.744 \\
\hline & LK2 & 0.793 \\
\hline & LK3 & 0.795 \\
\hline & LK4 & 0.730 \\
\hline & LK5 & 0.853 \\
\hline & LK6 & 0.740 \\
\hline \multirow{10}{*}{$\begin{array}{l}\text { Work Satisfaetion- } \\
\text { (Xmed) }\end{array}$} & Kp1 & 0.663 \\
\hline & KP2 & 0.744 \\
\hline & KP3 & 0.700 \\
\hline & KP4 & 0.762 \\
\hline & KP5 & 0.716 \\
\hline & KP6 & 0.776 \\
\hline & KP7 & 0.791 \\
\hline & KP8 & 0.776 \\
\hline & KP9 & 0.838 \\
\hline & KP10 & 0.746 \\
\hline
\end{tabular}

\begin{tabular}{|c|c|c|}
\hline Variable & Indicator & Outleading \\
\hline \multirow{18}{*}{$\begin{array}{l}\text { Turnover } \\
\text { Intention }(r)\end{array}$} & TO1 & 0.700 \\
\hline & TO2 & 0.545 \\
\hline & TO3 & 0.778 \\
\hline & TO4 & 0.704 \\
\hline & TO5 & 0.777 \\
\hline & TO6 & 0.675 \\
\hline & TO7 & 0.693 \\
\hline & TO8 & 0.691 \\
\hline & TO9 & 0.669 \\
\hline & TO10 & 0.788 \\
\hline & T011 & 0.598 \\
\hline & T012 & 0.766 \\
\hline & TO13 & 0.653 \\
\hline & T014 & 0.671 \\
\hline & T015 & 0.788 \\
\hline & T016 & 0.606 \\
\hline & T017 & 0.693 \\
\hline & T018 & 0.744 \\
\hline
\end{tabular}

According to the first calculation, there had several indicators which are invalid, so they will removed from these model then second calculation was carried out.

Table 2. Convergent Validity 2
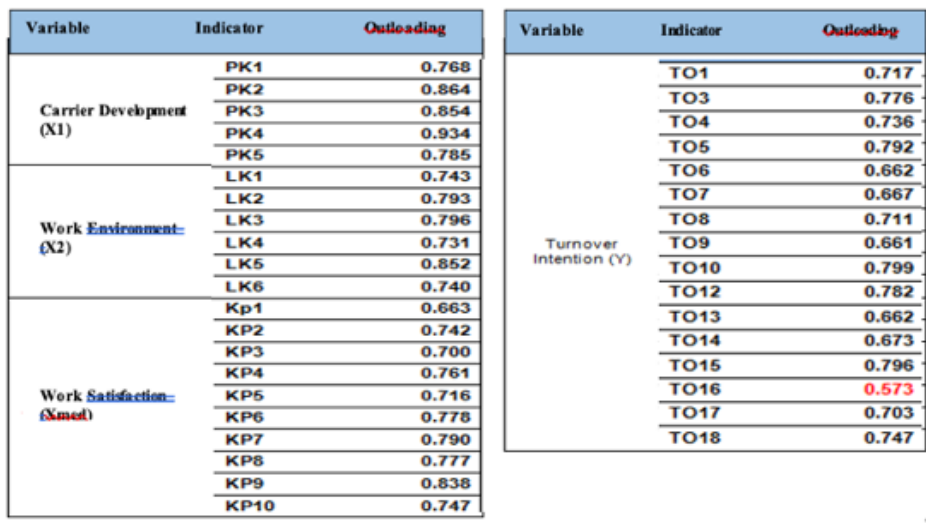

Based on these second calculation, there had indicator which invalid, so it would removed from the model then carried out the third calculation. 
Table 3. Convergent Validity 3

\begin{tabular}{|c|c|c|c|c|c|}
\hline Variable. & Indicator. & Outloading & Variable. & Indicator. & Outloadina \\
\hline \multirow{5}{*}{$\begin{array}{l}\text { Carrier } \\
\text { Development } \\
\text { (X1) }\end{array}$} & PK1 & 0.768 & \multirow{15}{*}{$\begin{array}{l}\text { Turnover } \\
\text { Intention }(\mathrm{l})\end{array}$} & TO1 & 0.726 \\
\hline & PK2 & 0.864 & & TO3 & 0.767 \\
\hline & PK3 & 0.854 & & TO4 & 0.737 \\
\hline & PK4 & 0.934 & & TO5 & 0.791 \\
\hline & PK5 & 0.785 & & TO6 & 0.674 \\
\hline \multirow{6}{*}{$\begin{array}{l}\text { Work } \\
\text { Environment } \\
\text { (X2) }\end{array}$} & LK1 & 0.743 & & TO7 & 0.661 \\
\hline & LK2 & 0.793 & & TO8 & 0.704 \\
\hline & LK3 & 0.796 & & TO9 & 0.652 \\
\hline & LK4 & 0.731 & & TO10 & 0.791 \\
\hline & LK5 & 0.852 & & TO12 & 0.790 \\
\hline & LK6 & 0.740 & & TO13 & 0.675 \\
\hline \multirow{10}{*}{$\begin{array}{l}\text { Work } \\
\text { satisfaction } \\
\text { (Xmed) }\end{array}$} & Kp1 & 0.663 & & TO14 & 0.680 \\
\hline & KP2 & 0.741 & & TO15 & 0.802 \\
\hline & KP3 & 0.700 & & T017 & 0.706 \\
\hline & KP4 & 0.761 & & TO18 & 0.754 \\
\hline & KP5 & 0.716 & & & \\
\hline & KP6 & 0.778 & & & \\
\hline & KP7 & 0.790 & & & \\
\hline & KP8 & 0.776 & & & \\
\hline & KP9 & 0.837 & & & \\
\hline & KP10 & 0.748 & & & \\
\hline
\end{tabular}

Furthermore, discriminant validity test was carried out based on cross loading result and was declared valid.

Table 4. Discriminant Validity

\begin{tabular}{cccccc} 
Indikator & PK & LK & KP & TO & Ket \\
\hline PK1 & 0.768 & 0.505 & 0.668 & -0.362 & Valid \\
\hline PK2 & 0.864 & 0.708 & 0.737 & -0.421 & Valid \\
\hline PK3 & 0.854 & 0.659 & 0.75 & -0.377 & Valid \\
\hline PK4 & 0.934 & 0.593 & 0.747 & -0.438 & Valid \\
\hline PK5 & 0.785 & 0.581 & 0.618 & -0.394 & Valid \\
\hline LK1 & 0.625 & 0.743 & 0.538 & -0.238 & Valid \\
\hline LK2 & 0.493 & 0.793 & 0.555 & -0.404 & Valid \\
\hline LK3 & 0.623 & 0.796 & 0.587 & -0.358 & Valid \\
\hline LK4 & 0.429 & 0.731 & 0.436 & -0.2 & Valid \\
\hline LK5 & 0.668 & 0.852 & 0.708 & -0.412 & Valid \\
\hline LK6 & 0.506 & 0.74 & 0.539 & -0.349 & Valid \\
\hline KP1 & 0.604 & 0.655 & 0.663 & -0.381 & Valid \\
\hline KP2 & 0.636 & 0.406 & 0.741 & -0.31 & Valid \\
\hline KP3 & 0.649 & 0.458 & 0.7 & -0.466 & Valid \\
\hline KP4 & 0.68 & 0.522 & 0.761 & -0.35 & Valid \\
\hline KP5 & 0.545 & 0.595 & 0.716 & -0.485 & Valid \\
\hline KP6 & 0.695 & 0.66 & 0.778 & -0.509 & Valid \\
\hline KP7 & 0.607 & 0.453 & 0.79 & -0.363 & Valid \\
\hline KP8 & 0.561 & 0.606 & 0.776 & -0.346 & Valid \\
\hline KP9 & 0.688 & 0.536 & 0.837 & -0.342 & Valid \\
\hline KP10 & 0.606 & 0.576 & 0.748 & -0.386 & Valid \\
\hline
\end{tabular}

\begin{tabular}{cccccc} 
Indikator & PK & LK & KP & TO & Ket \\
\hline TO1 & -0.406 & -0.332 & -0.468 & 0.726 & Valid \\
\hline TO3 & -0.367 & -0.382 & -0.406 & 0.767 & Valid \\
\hline TO4 & -0.238 & -0.294 & -0.287 & 0.737 & Valid \\
\hline TO5 & -0.372 & -0.316 & -0.409 & 0.791 & Valid \\
\hline TO6 & -0.312 & -0.301 & -0.375 & 0.674 & Valid \\
\hline TO7 & -0.283 & -0.157 & -0.268 & 0.661 & Valid \\
\hline TO8 & -0.41 & -0.389 & -0.492 & 0.704 & Valid \\
\hline TO9 & -0.289 & -0.236 & -0.321 & 0.652 & Valid \\
\hline TO10 & -0.267 & -0.294 & -0.367 & 0.791 & Valid \\
\hline TO12 & -0.341 & -0.309 & -0.385 & 0.79 & Valid \\
\hline TO13 & -0.243 & -0.193 & -0.282 & 0.675 & Valid \\
\hline TO14 & -0.408 & -0.36 & -0.381 & 0.68 & Valid \\
\hline TO15 & -0.431 & -0.433 & -0.448 & 0.802 & Valid \\
\hline TO17 & -0.284 & -0.324 & -0.379 & 0.706 & Valid \\
\hline TO18 & -0.393 & -0.27 & -0.373 & 0.754 & Valid \\
\hline & & & & & \\
& & & & &
\end{tabular}

Furthermore, reliability test was carried out based on composite reliability and cronbach's alpha with each condition above 0.70 so the instrument will be considered as reliable.

Table 5. Raliability Test

\begin{tabular}{|lccl|}
\hline Variable & Composite Reliability & Terms & Information \\
\hline Career development. & 0.924 & $>0.7$ & Reliable \\
\hline Work environment & 0.901 & $>0.7$ & Realible \\
\hline Job satisfaction & 0.901 & $>0.7$ & Realible \\
\hline Turn Over & 0.944 & $>0.7$ & Realible \\
\hline
\end{tabular}




\section{Inner Model Evaluation}

The first stage was examined those coefficient of determination by looking at $\mathrm{R}$ Square value, whereas Ghozali \& Latan (2015) classifies the R-Square value as 0.75; 0.50; 0.25 which is the strong, moderate, and weak model.

Table 6. R-square

\begin{tabular}{|lc|}
\hline Variable & R Square \\
\hline Job satisfaction & 0.734 \\
\hline Turn Over & 0.862 \\
\hline
\end{tabular}

From these results it could be concluded that career development and work environment variables had moderately impact on work satisfaction and turnover intention. Furthermore, the Goodness of Fit Index (GoF) test was carried out.

GoF Index $=\sqrt{ }$ AVE $x R^{2}$

$$
\begin{aligned}
& =\sqrt{ }((0.711+0.604+0.566+0.532) / 4) \times((0.734+0.286) / 2) \\
& =\sqrt{ }(0.603 \times 0.51) \\
& =0.554
\end{aligned}
$$

From these calculation results, the GoF Index value was considered large because the value was more than 0.36 . Then the last step was examined the hypothesis, whereas the $t$ table

\begin{tabular}{|c|c|c|c|}
\hline Relationship betweet constructs & $\begin{array}{l}\text { Original } \\
\text { sample }\end{array}$ & T Statistics & P Values \\
\hline \multicolumn{4}{|l|}{ Direct } \\
\hline Career development -> Turn Over & -0.069 & 0.475 & 0.648 \\
\hline Career development $->$ Job satisfaction & 0.946 & 7.941 & 0 \\
\hline Job satisfaction -> Turnover & -0.411 & 2.648 & 0.008 \\
\hline Job environment $->$ Job satiscation & 0.264 & 3.341 & 0.001 \\
\hline Job environment $->$ Turn Over & -0.081 & 0.622 & 0.534 \\
\hline \multicolumn{4}{|l|}{ Indecrect } \\
\hline Career development $->$ Job satisfaction $->$ Turn Over & -0.266 & 2.486 & 0.013 \\
\hline Job environment $->$ Job satisfaction $->$ Turn Over & -0.109 & 2.077 & 0.038 \\
\hline \multicolumn{4}{|l|}{ Total } \\
\hline Career development -> turn On & -0.266 & 0.486 & 0.013 \\
\hline Job environment $->$ Turn Over & -0.109 & 2.077 & 0.038 \\
\hline
\end{tabular}
value was obtained of 1.97377 with significance level $(\alpha)$ of 0.05 .

Table 7. Path Coefficients

The results shows that the direct effects of career development had insignificant impact on turnover. These results were in line with previous research that conducted by Saklit (2017), and contradict with Yasar and Nugraheni's research (2017). However, when its mediated by work satisfaction, career development were turn into negative and significant impact on turnover. Career development were also had positive and significant influence on work satisfaction and were in line with Yanjun Guan's research (2017) then work satisfaction had negative and significant impact on turnover and were in line with research by $\mathrm{Na} \mathrm{Li}$, Lichuan Zhang (2019). This continuation between career development that influence on work 
satisfaction and ultimately work satisfaction would impact on turnover. In this case work satisfaction acts as a perfect mediator between career development and turnover.

These research results was indicated that direct effect from work environment had insignificant impact towards turnover. This result was contrary to Irvianti and Verina's research (2015). However, when it was mediated by work satisfaction, work environment turn into negative and significant influence on turnover then Work environment were also had positive and significant influence on work satisfaction and were in line with Eun Kyoung Chung's research (2017) work satisfaction also had negative and significant impact on turnover and were in line with Eun Kyoung Chung's research (2017). This becomes a continuity between work environment which had influence over work satisfaction and ultimately work satisfaction affects the turnover. In this case work satisfaction acts as a perfect mediator between work environment and turnover.

\section{CONCLUSION}

According to research results it could be concluded that direct effect of career development on turnover gave negative but insignificant results, but the indirect effect which mediated by work satisfaction showed that career development had negative and significant impact towards turnover intention. So, it could be said that work satisfaction was perfectly mediated those influenced from career development towards turnover. Then the direct influence from work environment to turnover gave negative but insignificant results, but the indirect effect which mediated by work satisfaction showed that work environment had negative and significant influence on turnover. So, it could be said that work satisfaction was perfectly mediated those influence from work environment towards turnover intention.

\section{REFERENCES}

Armstrong, M. (2009). Armstrong's Handbook of Human Resource Management Practice. Kopanpage. London dan Philadelphia.

Dessler, Gray. (2015). Human Resources Management. Edisi 14. Penerbit Salemba Empat. Jakarta.

Eun Kyoung Chung, Yeseul Jung, Young Woo Sohn (2017). A Moderated Mediation Model Of Job Stress, Job karirction, and Turnover Intention for Airport Security Screeners. Journal of Safety Science.

F. Luthans. (2011). Organizational Behavior: An Evidence-Based Approach. New York, McGraw-Hill Education.

Ghozali, I. and H. Latan. (2015). Konsep, Teknik, Aplikasi Menggunakan Smart PLS 3.0 Untuk Penelitian Empiris, Semarang, BP Undip.

Guan Yanjun, Peng Jiang, Zhen Wang, Zichuan Mo dan Fei Zhu. (2017).Self- Referent and Other-Referent Career Successes, Career Satisfaction, and Turnover Intention Among Chinese Employees: The Role of Achievement Motivation. Journal of Career Development, 44(5).

Irvianti Laksmi Sito Dwi dan Renno Eka Verina. (2015). Analisis Pengaruh Stres Kerja, Beban Kerja, dan Lingkungan Kerja Terhadap Turnover Intention Karyawan pada PT XL Axiata TBK Jakarta. Binus Business Review, Vol. 6 No. 1. 
Kasmir. (2016). Manajemen Sumber Daya Manusia (Teori dan Praktik). Raja Grafindo Persada. Jakarta.

Mathis, Robert L. dan Jackson John H. (2010). Human Resource Management.13th ed.Thomson. South-Western.

$\mathrm{Na} \mathrm{Li,} \mathrm{Lichuan} \mathrm{Zhang,} \mathrm{Guangqing} \mathrm{Xiao,} \mathrm{Jie} \mathrm{Chen,} \mathrm{Qian} \mathrm{Lu} \mathrm{(2019).} \mathrm{The} \mathrm{Relationship} \mathrm{Between}$ Workplace Violence, Job Satisfaction and Turnover Intention in Emergency Nurse. International Emergency Nursing.

Noe, Raymond A., et all. (2014). Human Resource Management. Mc Graw-Hill. New York.

Robbins, Stephen P, dan Mary Coulter. (2012). Management. Edisi 11. Person. New Jersey.

Saklit I Wayan. (2017). Pengaruh Gaya Kepemimpinan dan Pengembangan Karir Terhadap Intensi Turnover: Kepuasaan Kerja Sebagai Mediator. Jurnal Manajemen, Volume XXI, No. 03: 472-490.

Sedarmayanti. (2015). Tata Kerja dan Produktivitas Kerja. Bandung, CV Mandar Maju.

Sutrisno, Edy. (2011). Manajemen Sumber Daya Manusia. Kencana Prenada Media Group. Jakarta.

Tobias Murtantyo (2015). Pengaruh Pengembangan Karir, Lingkungan Kerja dan Kompensansi terhadap Turnover Intention di PT. Yakult Indonesia Persada. Jurnal Manajemen, Volume XXI, No. 03: 472-490.

Yasar Muhammad Miftah Babil dan Rini Nugraheni. (2017). Analisis Pengaruh Kepuasan Gaji dan Pengembangan Karir terhadap Kepuasaan Kerja Serta Dampaknya terhadap Turnover Intention. Diponegoro Journal of Management, Volume 6, Nomor 4, Halaman 1-10.Lampung. 